\title{
Perancangan Dan Implementasi Aplikasi Bagus! Laundry Berbasis Website
}

\author{
Witta Listiya Ningrum ${ }^{1}$, Muhammad Ivan Hidayatullah ${ }^{2}$, Sugeng Santoso ${ }^{3}$ \\ ${ }^{1,2}$ Jurusan Sistem Informasi Universitas Gunadarma, ${ }^{3}$ Jurusan Teknik Informatika Universitas Raharja \\ e-mail: *11wita_listiya@staff.gunadarma.ac.id, ${ }^{2}$ muh.ivan37@gmail.com, \\ ${ }^{3}$ sugeng.santoso@raharja.info
}

\begin{abstract}
Abstrak
Seiring cepat dan pesatnya perkembangan pada dunia teknologi dan informasi, segala hal yang ada di dunia ini perlahan akan beralih ke teknologi yang lebih efisien. Kemajuan teknologi ini juga berperan dalam bidang bisnis seperti jasa laundry. Untuk memudahkan dalam mengelola data, Bagus! Laundry memerlukan sebuah pencatatan data konsumen, data transaksi, data paket, dan laporan. Selama ini Bagus! Laundry masih menggunakan metode konvensional yaitu pencatatan data menggunakan kertas yang mudah hilang dan rusak. Dalam pembuatan website ini menggunakan Bahasa pemrograman PHP yang digunakan untuk membuat halaman website dan MySQL sebagai database tempat penyimpanan data. Hasil ujicoba menggunakan metode blackbox testing didapatkan hasil bahwa semua fungsionalitas pada website Bagus! Laundry berjalan seperti yag diharapkan.
\end{abstract}

Kata Kunci-Situs Web, Laundry, PHP, MySQL, Blackbox

\begin{abstract}
Along with the fast and rapid development in the world of technology and information, everything in this world will slowly shift to more efficient technology. These technological advances also play a role in business fields such as laundry services. To make it easier to manage data, Good! Laundry requires a record of consumer data, transaction data, package data, and reports. So far good! Laundry still uses the conventional method of recording data using paper that is easily lost and damaged. In making this website using the PHP programming language which is used to create web pages and MYSQL as a database for data storage. The results of the trial using the blackbox testing method showed that all the functionality on the website was good! Laundry went as expected.
\end{abstract}

Keywords - Laundry, PHP, MySQL, Blackbox

\section{PENDAHULUAN}

Seiring cepat dan pesatnya perkembangan pada dunia teknologi dan informasi, segala apapun hal yang ada di dunia ini perlahan akan terbantu dengan adanya teknologi dan informasi. Masyarakat pun perlahan akan sangat membutuhkan peran teknologi dan informasi untuk memenuhi kebutuhan masing - masing agar hal yang mereka butuhkan akan lebih cepat dan efisien. Dalam dunia bisnis peran teknologi sangat bermanfaat untuk memenuhi kebutuhan dan menunjang kemajuan usaha. Dengan peran sistem komputer yang dapat mengelola informasi dengan cepat, maka teknologi sangat berperan penting dalam perkembangan bisnis. Seperti bisnis dalam bidang jasa, salah satunya adalah Laundry.

Laundry merupakan jasa pencucian dan perawatan pakaian, jasa laundry memiliki kelebihan yaitu mencuci dan menyetrika dengan instan, harum, dan cepat.Dengan memiliki kelebihan tersebut, jasa laundry sangat dibutuhkan oleh masyarakat. Saat ini Bagus! Laundry masih menggunakan sistem konvensional yaitu mencatat data transaksi menggunakan kertas nota secara manual. Dengan menggunakan metode tersebut, tidak jarang menimbulkan kendala seperti kertas mudah rusak, robek atau hilang. Dan yang paling fatal adalah kekeliruan dalam pencatatan data dan pelaporan keuangan. 


\section{METODE PENELITIAN}

Metode yang digunakan dalam rancang bangun website ini adalah SDLC (System Development Life Cycle). SDLC adalah tahapan pekerjaan yang dilakukan oleh programmer dan analisis sistem dalam mengembangkan sistem informasi (Raymond, 2010). Tahapan-tahapan pada penelitian ini meliputi :

1. Tahap Perencanaan

Tahapan awal yang dilakukan pada pembuatan website ini yaitu melakukan perencanaan seperti mengidentifikasi masalah.

2. Tahap Analisis

Tahapan ini dilakukan untuk menganalisis kebutuhan software dan hardware dalam melakukan pembuatan website.

2. Tahap Perancangan

Pada tahap ini dilakukan pembuatan rancangan menggunakan struktur navigasi, usecase diagram, perancangan basis data dan juga perancangan tampilan.

4. Tahap Impelementasi

Tahapan implementasi merupakan tahap penciptaan perangkat lunak, tahap kelanjutan dari kegiatan perancangan sistem.

5. Tahap Pengujian

Tahap ujicoba dilakukan menggunakan metode Blackbox testing untuk menguji

fungsionalitas pada website.

\section{HASIL DAN PEMBAHASAN}

Pada bab ini akan dijelaskan mengenai pembahasan dan hasil yang dilakukan pada penelitian, dimulai dengan tahapan-tahapan seperti berikut :

\subsection{Tahap Perencanaan}

Pada tahap perencanaan ini akan dibahas tentang bagaimana merancang dan membangun website Bagus! Laundry. Melalui hasil observasi dengan mewawancarai pemilik laundry, pegawai laundry masih melakukan pencatatan data transaksi secara manual pada nota. Masalah yang sering dijumpai antara lain seperti hilangnya kertas nota dan kertas mudah sekali robek, dan juga terkadang keliru dalam pencatatan.

\subsection{Tahap Analisis}

Pada tahapan analisis ini dilakukan proses identifikasi kebutuhan mengenai website ini, apa saja kebutuhan fungsional yang dibutuhkan pada website ini. Diharapkan website ini dapat membbantu admin dalam mengelola laundry dengan lebih efisien dan minim kesalahan. Analisis pengguna mencirikan pengguna dari website ini. Website Bagus! Laundry memiliki satu jenis pengguna, yaitu admin. User merupakan pengguna yang bertanggung jawab dalam mengelola data konsumen, data paket, data transaksi, dan laporan.

\subsection{Tahap Perancangan}

Pada tahap perancangan ini akan dibuat skema perancangan pada aplikasi Bagus! Laundry menggunakan struktur navigasi, diagram UML (Unified Modelling Language) yang terdiri dari diagram use case, perancangan basis data dan juga perancangan tampilan.

\subsubsection{Struktur Navigasi}

Struktur navigasi adalah gabungan dari struktur refrensi informasi situs web dan mekanisme link yang mendukung pengunjung untuk melakukan penjelajahan situs [1]. Struktur navigasi yang digunakan dalam website ini adalah struktur navigasi campuran. Struktur navigasi campuran disebut juga struktur navigasi bebas yang merupakan gabungan dari struktur navigasi linier, non linier dan hirarki. 
ISSN : $2356-\mathbf{5 1 9 5}$

Online ISSN: 2654 - 8704

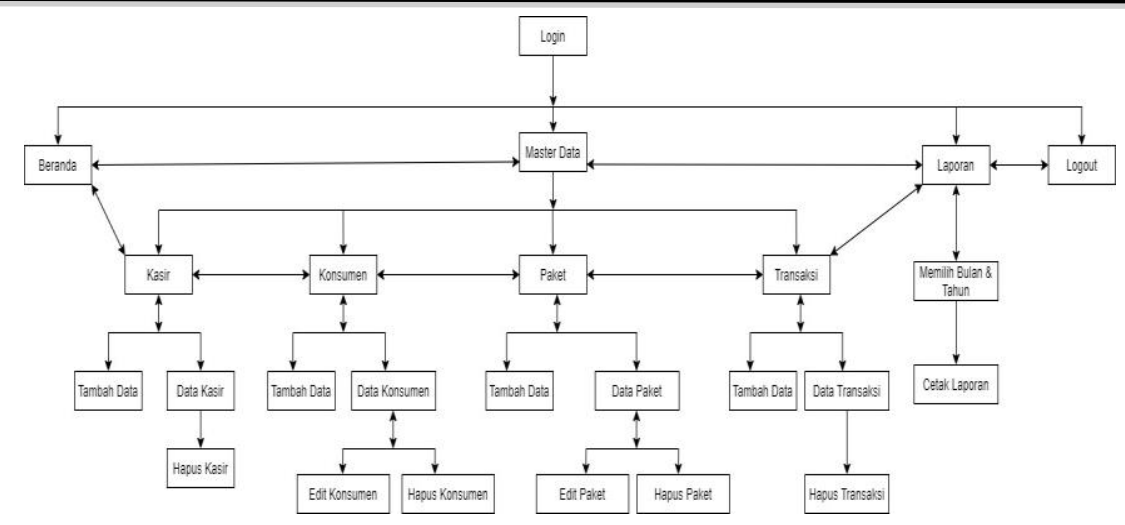

Gambar 1. Struktur Navigasi

\subsubsection{Use Case Diagram}

Use Case Diagram digunakan untuk menggambarkan sebuah interaksi antara user dan interface [2]. Pada Gambar 2 merupakan use case diagram pada aplikasi menu makanan khas kota Jakarta. User dapat melihat detail resep makanan yang dipilih, melihat video dari web youtube dan dapat mengakses menu About.

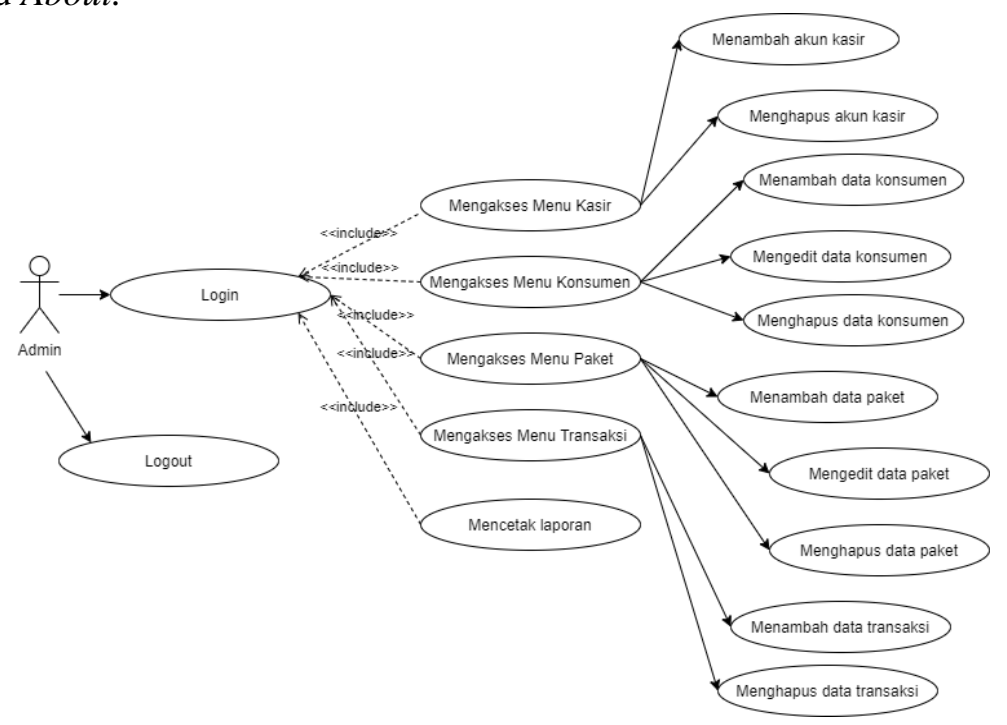

Gambar 2. Use Case Diagram

\subsubsection{Perancangan Basis Data}

Sebuah website dibutuhkan basis data atau sebuah penyimpanan untuk menyimpan data-data yang ada di website tersebut. Di dalam website bagus! laundry terdapat 4 tabel yang akan dibuat pada rancangan tabel, yaitu tabel kasir, konsumen, paket, dan transaksi.

Tabel 3.1 Tabel Kasir

\begin{tabular}{|l|l|l|l|}
\hline Field & Tipe & Ukuran & Keterangan \\
\hline id_kasir & varchar & 4 & Primary Key \\
\hline nama & varchar & 50 & \\
\hline password & varchar & 10 & \\
\hline level & varchar & 20 & \\
\hline
\end{tabular}


ISSN : $2356-5195$

Online ISSN: 2654 - 8704

Tabel 3.2. Tabel Konsumen

\begin{tabular}{|l|l|l|l|}
\hline Field & Tipe & Ukuran & Keterangan \\
\hline id_konsumen & varchar & 7 & Primary Key \\
\hline nama & varchar & 50 & \\
\hline alamat & text & & \\
\hline hp & varchar & 13 & \\
\hline
\end{tabular}

Tabel 3.3 Tabel Paket

\begin{tabular}{|l|l|l|l|}
\hline Field & Tipe & Ukuran & Keterangan \\
\hline id_paket & varchar & 5 & Primary Key \\
\hline nama & varchar & 50 & \\
\hline harga & varchar & 5 & \\
\hline
\end{tabular}

Tabel 3.4 Tabel Transaksi

\begin{tabular}{|l|l|l|l|}
\hline Field & Tipe & Ukuran & Keterangan \\
\hline id_transaksi & varchar & 7 & Primary Key \\
\hline id_kasir & varchar & 4 & \\
\hline id_konsumen & varchar & 7 & \\
\hline id_paket & varchar & 5 & \\
\hline tgl_transaksi & date & & \\
\hline jml_kilo & varchar & 2 & \\
\hline total & varchar & 6 & \\
\hline
\end{tabular}

\subsubsection{Rancangan Tampilan Website}

Pada tahapan ini akan digambarkan rancangan tampilan website yang akan dibuat. Akan dijelaskan satu persatu mengenai tahapan bagaimana membuat perancangan website ini.

\subsubsection{Rancangan Halaman Login}

Halaman login adalah kunci untuk dapat mengakses sebuah sistem dan hanya admin yang terdata dalam database yang dapat mengaksesnya. Terdapat textbox untuk memasukkan username dan password, dan tombol submit untuk mengakses sistem. Rancangan halaman login dapat dilihat pada gambar 3. 


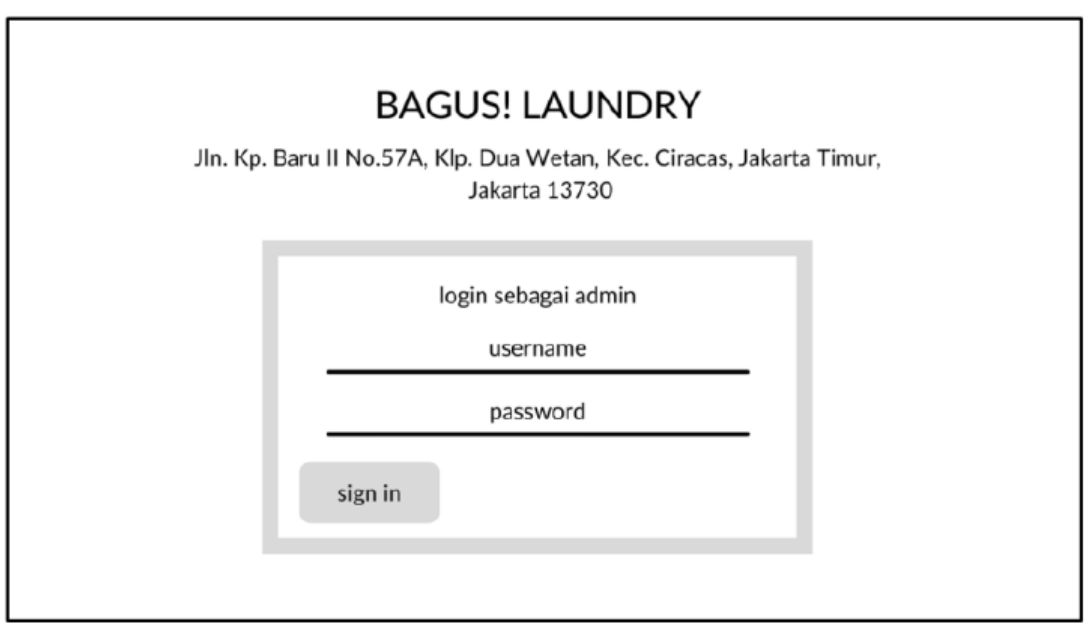

Gambar 3. Tampilan Halaman Login

\subsubsection{Rancangan Halaman Beranda}

Tampilan beranda adalah tampilan yang akan muncul setelah admin berhasil login. Dashboard akan berisi navbar header dan navbar side. Pada navbar side terdapat tombol master data yang akan memunculkan menu kasir, konsumen, paket, transaksi, laporan dan terdapat button untuk logout. Gambar dapat dilihat pada gambar 4.

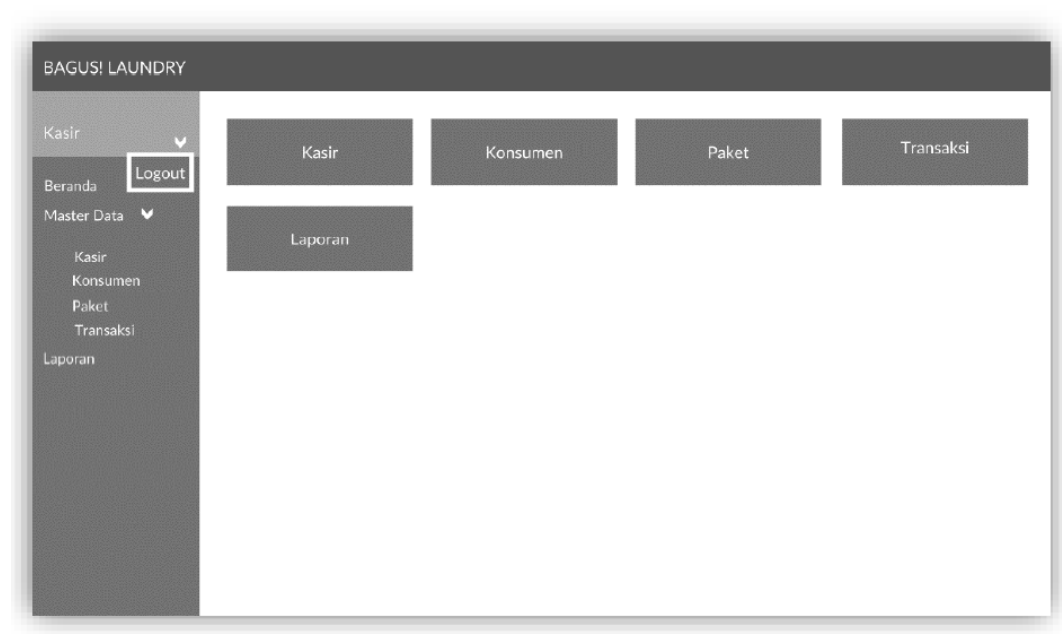

Gambar 4. Tampilan Halaman Beranda

\subsubsection{Rancangan Halaman Kasir}

Tampilan navbar header dan navbar side sama seperti pada halaman beranda. Tampilan halaman kasir berisi tabel data informasi mengenai kasir atau admin yang terdaftar didalam database sistem. Pada halaman kasir terdapat tombol tambah untuk menambahkan kasir, id kasir, nama kasir, password (ter-enkripsi), level, dan opsi hapus. Gambar dapat dilihat pada gambar 5. 


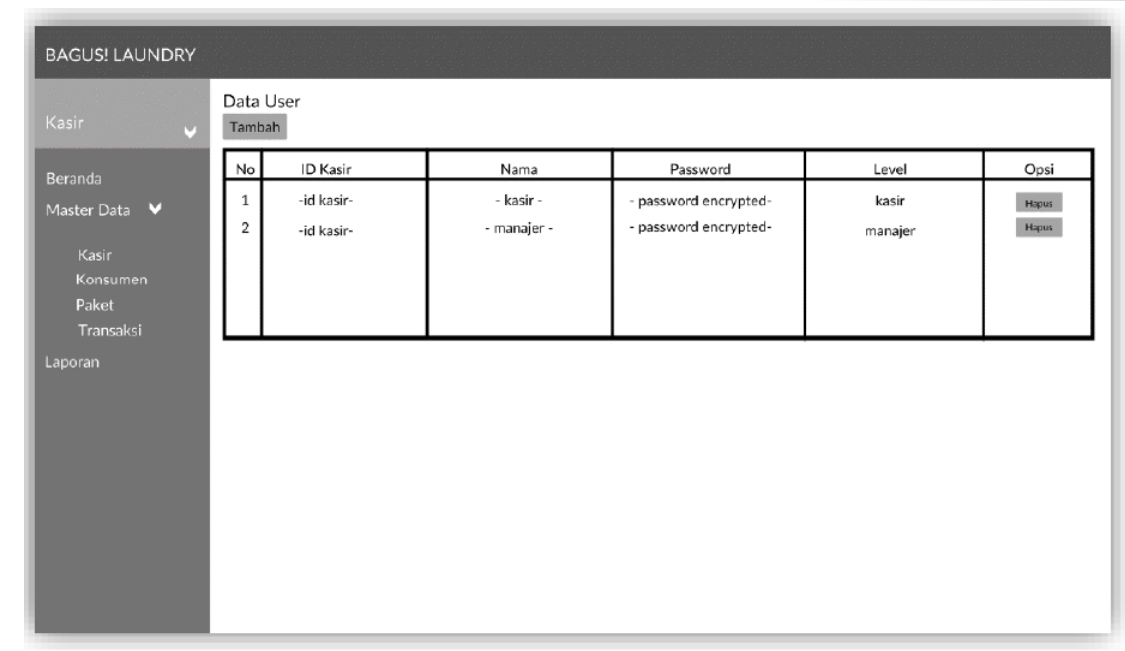

Gambar 5. Tampilan Halaman Kasir

\subsubsection{Rancangan Halaman Konsumen}

Tampilan navbar header dan navbar side sama seperti pada halaman beranda. Pada halaman konsumen, terdapat tabel mengenai informasi konsumen yang telah terdaftar pada sistem. Terdapat id konsumen, nama konsumen, nomor $\mathrm{hp}$, alamat, dan juga terdapat opsi tambah, edit dan hapus. Gambar dapat dilihat pada gambar 6.

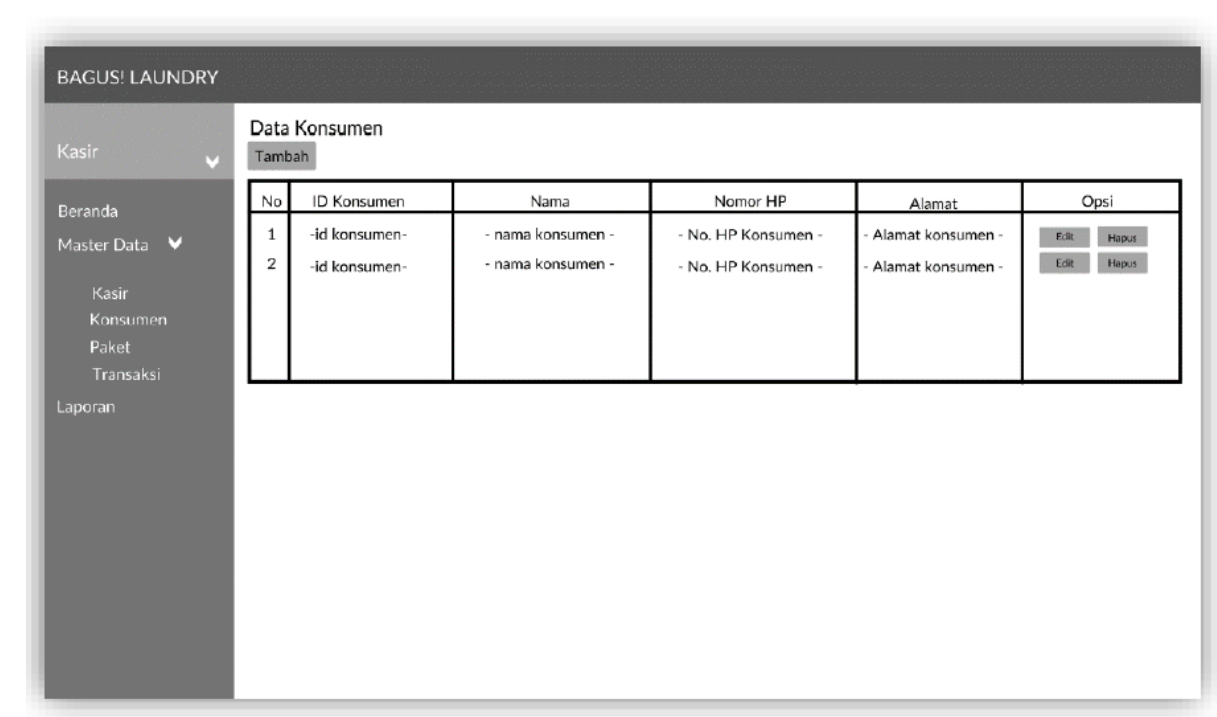

Gambar 6. Tampilan Halaman Konsumen

\subsubsection{Rancangan Halaman Paket}

Tampilan navbar header dan navbar side sama seperti pada halaman beranda. Pada halaman tambah paket terdapat id paket, dan admin dapat memasukan nama paket baru, harga paket tersebut, dan terdapat tombol simpan. Gambar dapat dilihat pada gambar 7. 
ISSN : $2356-5195$

Online ISSN: 2654 - 8704

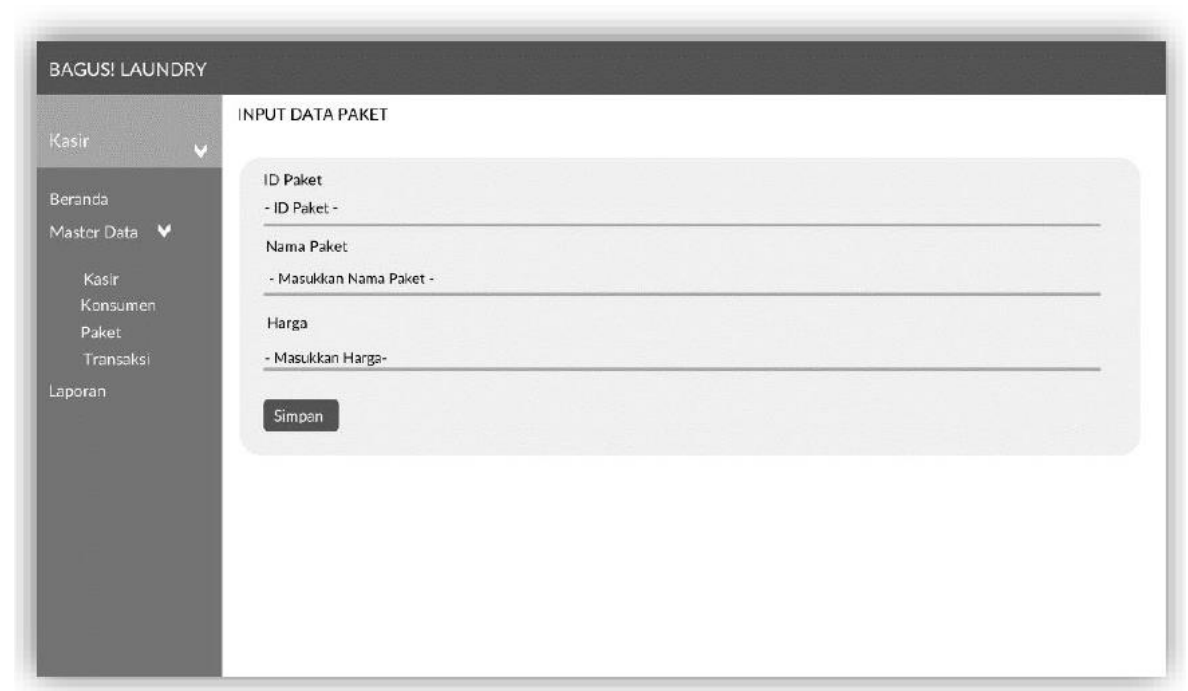

Gambar 7. Tampilan Halaman Tambah Paket

\subsubsection{Rancangan Halaman Transaksi}

Tampilan navbar header dan navbar side sama seperti pada halaman beranda. Halaman transaksi terdapat tombol tambah, dan berisi tabel data mengenai informasi transaksi yang telah masuk ke sistem. Terdapat id transaksi, nama kasir yang memasukkan data transaksi, nama konsumen, paket, tanggal transaksi, jumlah kilogram/pcs, total bayar dan terdapat opsi hapus. Gambar dapat dilihat pada gambar 8 .

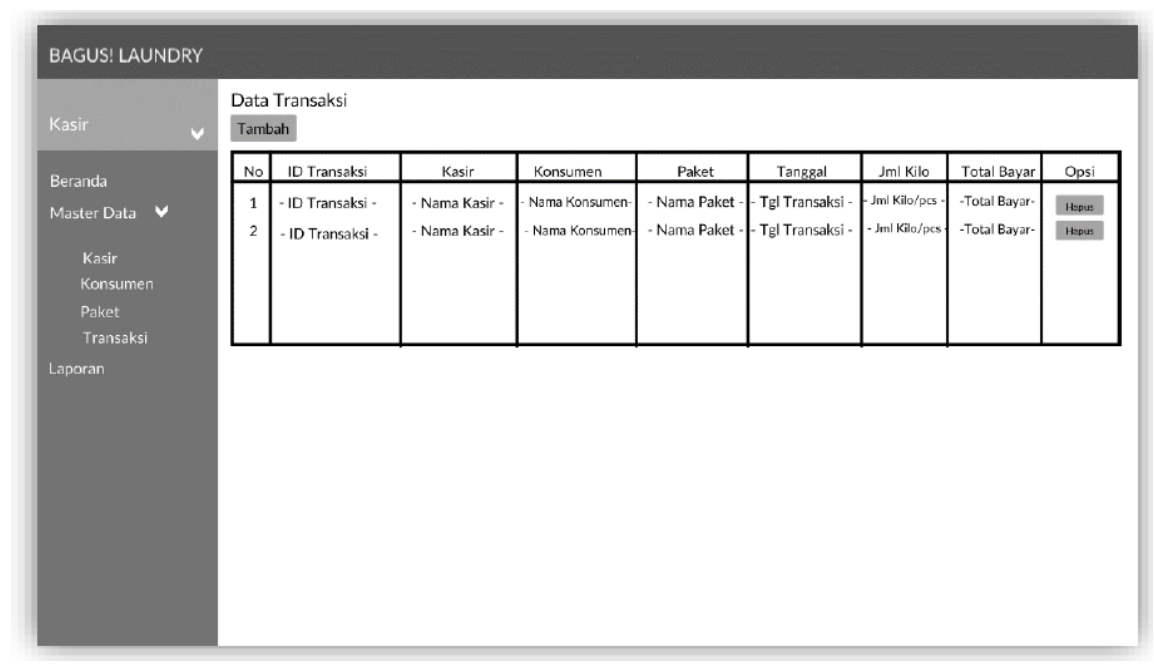

Gambar 8. Tampilan Halaman Transaksi

\subsubsection{Rancangan Halaman Transaksi}

Tampilan navbar header dan navbar side sama seperti pada halaman beranda. Pada halaman tambah transaksi, admin dapat menambahkan data transaksi baru, terdapat menu tanggal, id transaksi, id kasir, paket, jumlah kilo, id konsumen, nama konsumen, alamat konsumen, nomor hp konsumen, total nominal keseluruhan, dan tombol simpan. Gambar dapat dilihat pada gambar 9. 


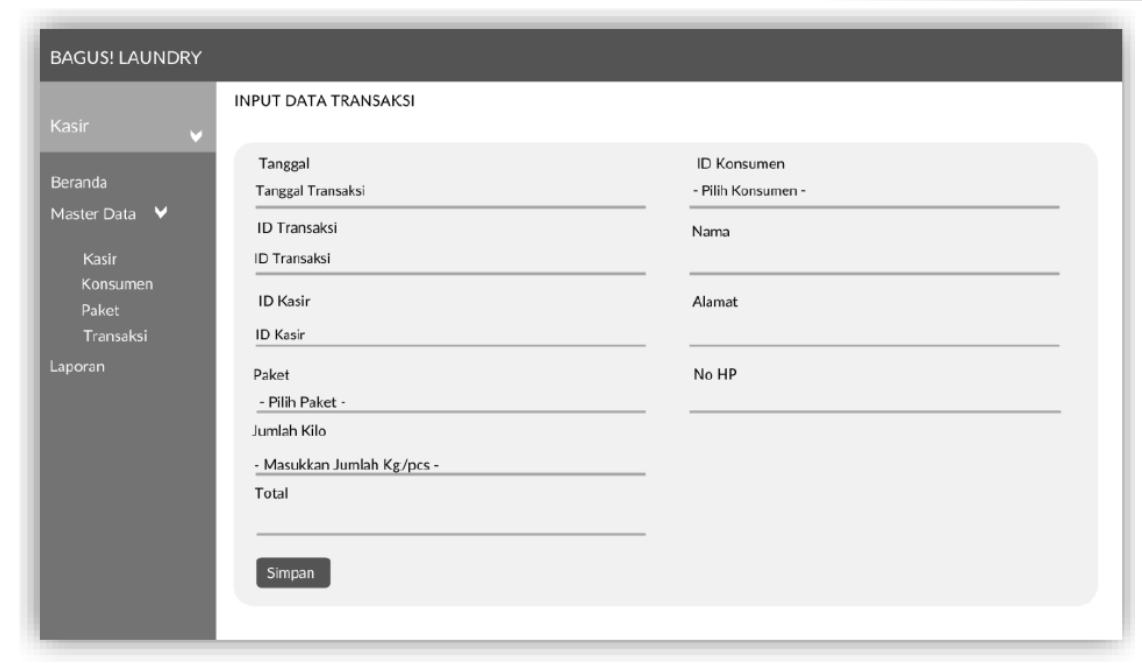

Gambar 9. Tampilan Halaman Tambah Transaksi

\subsubsection{Rancangan Halaman Laporan}

Tampilan navbar header dan navbar side sama seperti pada halaman beranda. Pada halaman laporan, admin dapat memilih bulan dan tahun, terdapat tabel mengenai transaksi pada bulan dan tahun yang ditentukan oleh admin, dan terdapat tombol print untuk mencetak laporan. Gambar dapat dilihat pada gambar 10 .

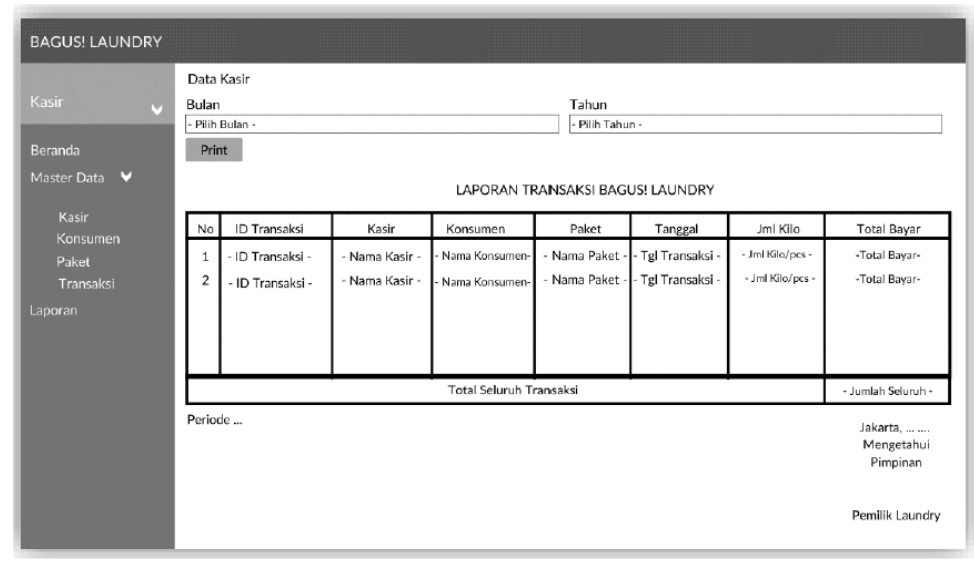

Gambar 10. Halaman Laporan

\subsection{Tahap Impelementasi}

Tahapan implementasi merupakan tahap penciptaan perangkat lunak, tahap kelanjutan dari kegiatan perancangan sistem. Tahap ini merupakan tahap dimana sistem siap untuk dioperasikan, yang terdiri dari penjelasan mengenai lingkungan implementasi, dan implementasi program. Untuk mendukung aplikasi yang diterapkan pada Bagus! Laundry, maka dalam hal ini menggunakan perangkat keras dan perangkat lunak yang menunjang dalam pembangunan aplikasi Bagus! Laundry. 
ISSN : $2356-5195$

Online ISSN: 2654 - 8704

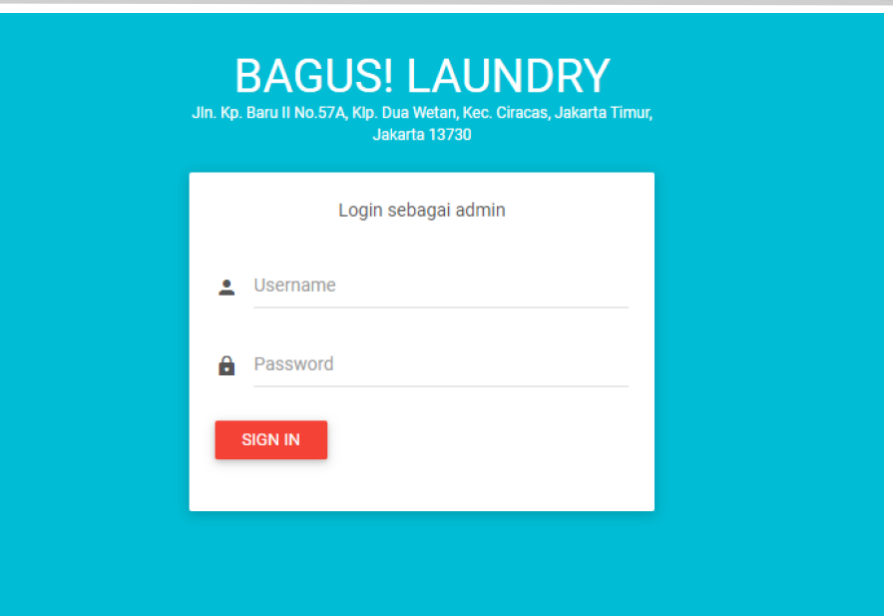

Gambar 11. Halaman Login

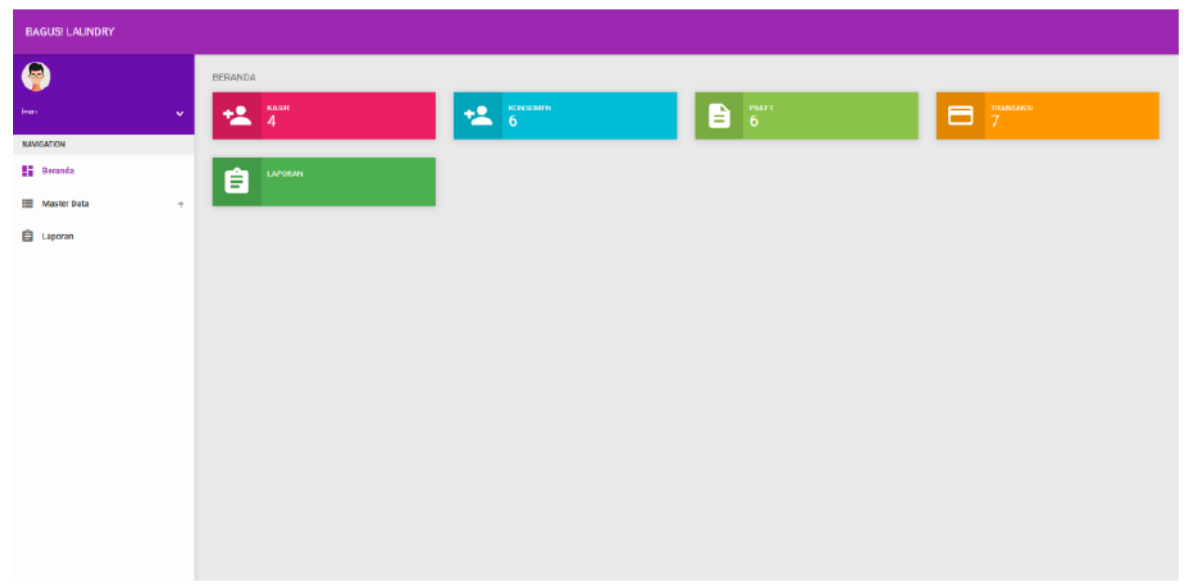

Gambar 12. Halaman Beranda

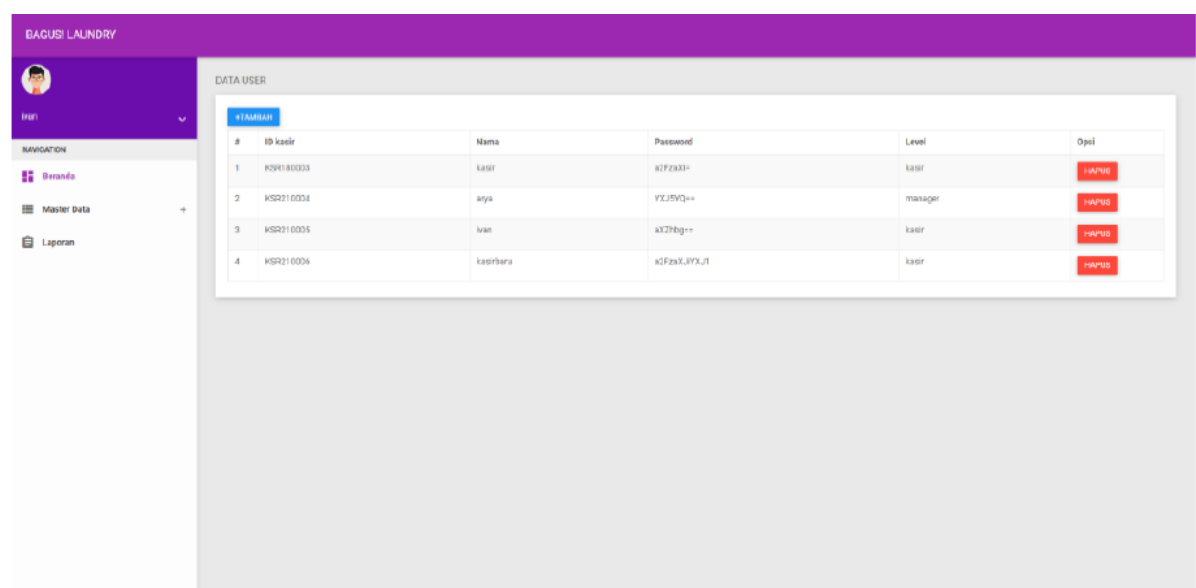

Gambar 13. Halaman Data Kasir 
ISSN : $2356-5195$

Online ISSN: 2654 - 8704

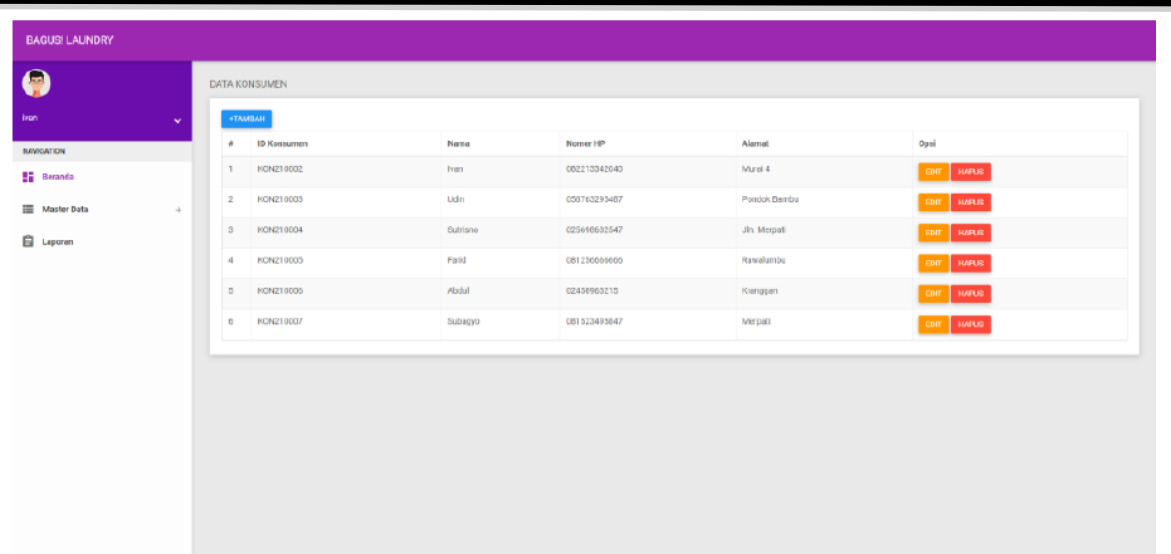

Gambar 14. Halaman Data Konsumen

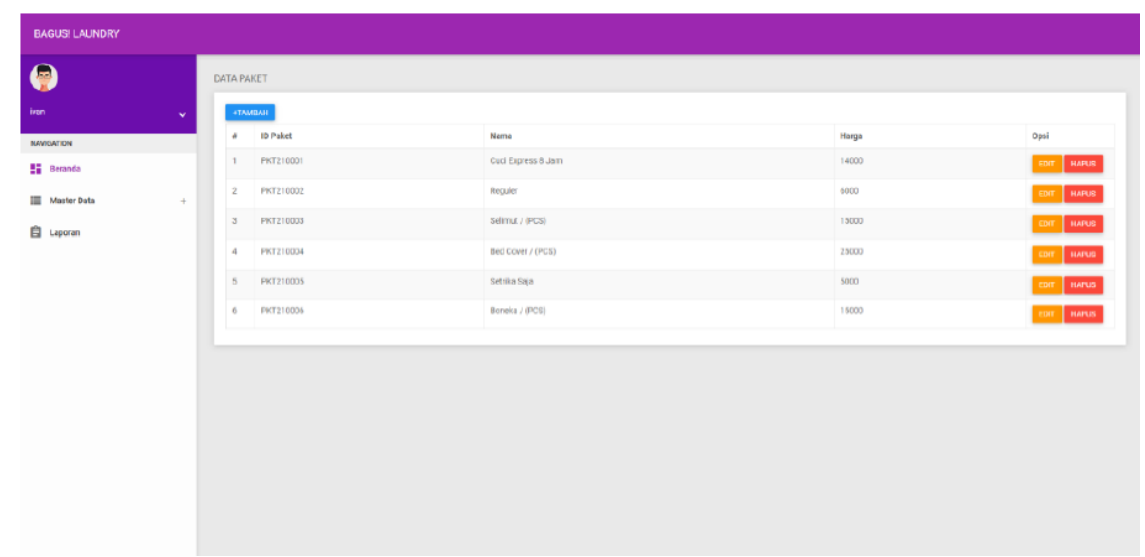

Gambar 15. Halaman Data Paket

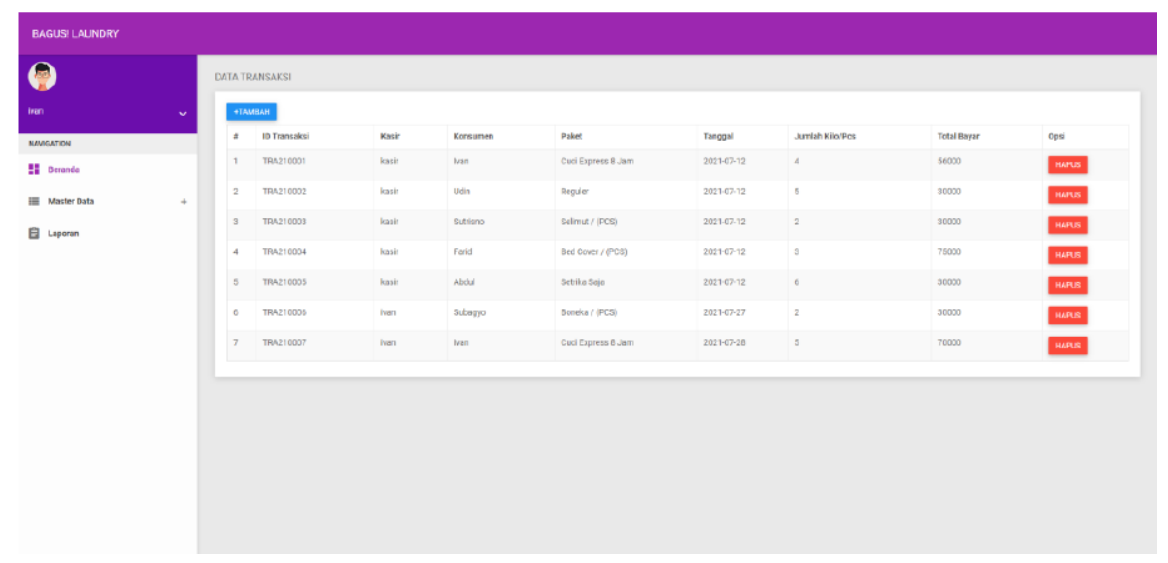

Gambar 16. Halaman Data Transaksi 


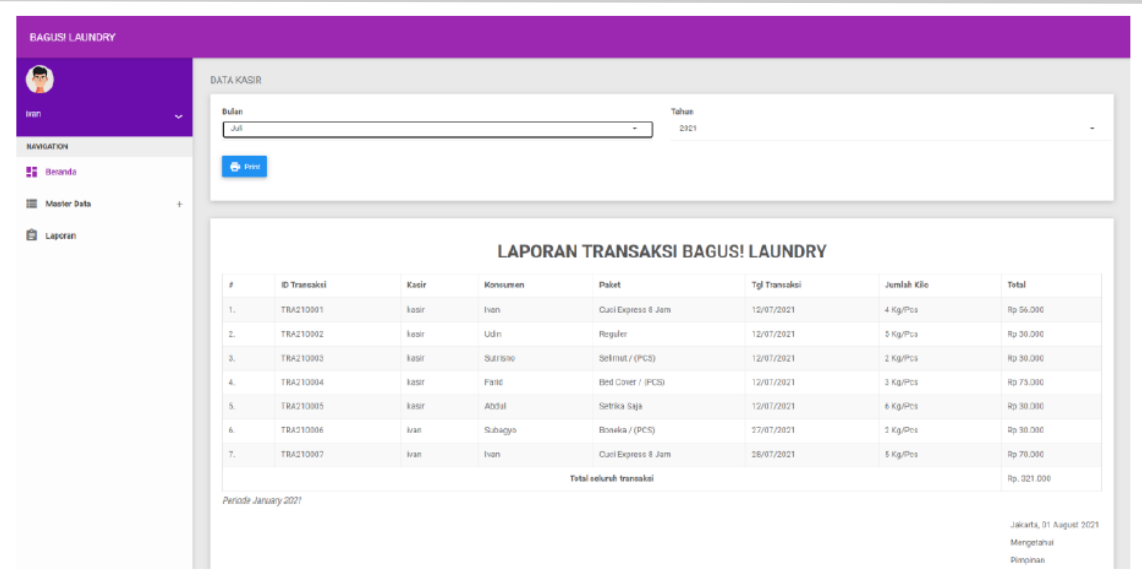

Gambar 17. Halaman Data Laporan

\subsection{Tahap Pengujian}

Sebelum website ini dapat digunakan, maka harus dilakukan pengujian terlebih dahulu. Beberapa pengujian dilakukan oleh penulis sendiri. Pengujian website Bagus! Laundry ini dilakukan dengan menggunakan pendekatan black box testing. Pengujian diperlukan sebagai salah satu tahapan implementasi untuk menguji tingkat minimal kesalahan dan keakuratan perangkat lunak yang dirancang. Pengujian dilakukan dengan metode pengujian black box. Black box testing merupakan pengujian yang memungkinkan software engineer mendapatkan serangkaian kondisi input yang sepenuhnya menggunakan semua persyaratan fungsional untuk suatu program [5].

Setelah melakukan uji coba pada website ini, dapat disimpulkan bahwa pengujian berjalan dengan baik sesuai dengan harapan. Semua halaman dan tombol fungsional berfungsi sebagai mana mestinya dan tidak ada error satupun pada website.

\section{KESIMPULAN}

Pada penelitian ini telah diuraikan metode yang dilakukan untuk menghasilkan sebuah website pada Bagus! Laundry meliputi tahapan perencanaan, analisis, perancangan, impelementasi dan pengujian. Pada tahap perencanaan dilakukan identifikasi masalah kemudian observasi dan wawancara, pada tahap analisis dilakukan untuk mengetahui kebutuhan untuk melakukan rancang bangun pada website ini, pada tahap perancangan dilakukan proses perancangan website menggunakan struktur navigasi, usecase diagram, perancangan basis data dan perancangan tampilan, Tahapan implementasi merupakan tahap penciptaan perangkat lunak, tahap kelanjutan dari kegiatan perancangan system, dan tahap pengujian dilakukan menggunakan metode black box testing untuk menguji fungsionalitas dari website Bagus! Laundry.

Pembuatan rancang bangun website Bagus! Laundry telah berhasil dibuat sesuai dengan yang dibutuhkan oleh Bagus! Laundry meliputi adanya rancangan tampilan untuk data kasir, data konsumen, data paket, data transaksi, dan cetak laporan. Hasil uji coba pada website ini, dapat disimpulkan bahwa pengujian berjalan dengan baik sesuai dengan harapan.

\section{SARAN}

Saran yang dapat penulis berikan dalam pengembangan website Bagus! Laundry yaitu jika ada fitur untuk konsumen supaya dapat melihat katalog dan informasi seputar laundry.

\section{DAFTAR PUSTAKA}

[1] Binanto, Iwan., 2010, Multimedia Digital Dasar Teori dan Pengembanganya., Andi Publisher, Yogyakarta.

[2] Nugroho, Adi., 2010, Rekayasa Perangkat Lunak Menggunakan UML Dan Java, Andi Publisher, Yogyakarta.

Vol 8 No 1 - Februari 2022 
ISSN : $2356-5195$

Online ISSN: 2654 - 8704

[3] Nugroho, B., 2008, Membuat Sistem Informasi Penjualan Berbasis Web dengan PHP dan $M y S Q L$, Gava Media, Yogyakarta.

[4] Pratama, Andre., 2017, MySQL Uncover - Panduan Belajar MySQL dan MariaDB untuk Pemula, Duniailkom.

[5] Pressman, Roger S., 2005, Software Engineering A Practitioner's Approach, McGraw-Hill International Edition, New York.

[6] Raymond McLeod, Jr., 2010, Management Information System, Prentice Hall. 